UDC 678.686

\author{
K.M. Sukhyy ${ }^{a}$, E.A. Belyanovskaya ${ }^{a}$, A. Nosova ${ }^{a}$, M.K. Sukhyy ${ }^{a}$, Y. Huang ${ }^{b}$, Yu. Kochergin ${ }^{b}$, \\ T. Hryhorenko ${ }^{b}$
}

\title{
PROPERTIES OF COMPOSITE MATERIALS BASED ON EPOXY RESIN MODIFIED WITH DIBUTYLTIN DIBROMIDE
}

\author{
a Ukrainian State University of Chemical Technology, Dnipro, Ukraine \\ ${ }^{b}$ Harbin Institute of Technology, Harbin, People's Republic of China
}

\begin{abstract}
A tin-bromine-containing resin was prepared by the interaction of industrial ED-16 epoxy resin with dibutyltin dibromide. A comparative study of the physical, mechanical and relaxation properties of composites based on the original and modified resins cured at different temperatures has been carried out. It has been shown that the composite materials based on a modified resin are characterized by lower values of tensile strength, elastic modulus, fracture work and glass transition temperature as compared with the samples based on the original epoxy resin. The effect of water on the deformation and strength properties of composites was studied. A complex mechanism of the influence of moisture sorbed by the polymer on the complex of properties has been established, which may result from the imposition of the effects of plasticization and additional curing of the epoxy matrix. At short exposure times, the effect of the sorbed liquid is mainly aimed at weakening the intermolecular interaction in the sample, as a result of which its tensile strength decreases and its deformation capacity increases. At long exposure times, postcuring processes prevail, leading to an increase in the crosslinking density and, as a consequence, to a decrease in deformation capacity and an increase in the strength index. It has been shown that epoxy composites containing resin modified with dibutyltin dibromide are characterized by increased fungitoxicity and fire resistance. The studied polymers can be considered as promising for the production of antifouling coatings for hydraulic equipment on their basis.
\end{abstract}

Keywords: epoxy composite, dibutyltin dibromide, physical and mechanical properties, fire resistance, fungitoxicity, antifouling fungal resistant coatings.

DOI: $10.32434 / 0321-4095-2021-137-4-118-125$

\section{Introduction}

Algae and shellfish overgrowth is one of the main problems affecting industrial heat exchangers, sea and river vessels. Settling on the surface of hydraulic engineering objects, fouling causes significant economic damage. The negative consequences of fouling cause reduction of heat transfer, loss of cooling efficiency, premature deterioration of facilities and increased operating and maintenance costs $[1-4]$. Fouling reduces the speed of ships (up to $50 \%$ ), increases fuel consumption (up to $40 \%$ ), increases the weight of hydraulic structures (up to 20\%), and disrupts the operation of platforms for oil and gas production on the shelf. Fouling is one of the main reasons for the failure of the underwater parts of ships, submarines and hydraulic structures, as well as oceanographic instruments that are in the water for a long time. Furthermore, marine organisms can break the insulation of electrical cables and damage metal cables.

Currently, the prevention of fouling is based on special coatings which contain copper or other toxic substances (biocides) that are more toxic and have a long service life [5-8]. A classic example is the use of powdered copper and its oxide in protective coatings that prevent the fouling of the bottom of ships from sea growth, as a biocide. To impart fungitoxicity, other metals and their salts are also used, first of all, tin [5]. Organotin polymers have high antimicrobial and antifungal activity [6,7]. In the composition of binders used in shipbuilding,

(C) K.M. Sukhyy, E.A. Belyanovskaya, A. Nosova, M.K. Sukhyy, Y. Huang, Yu. Kochergin, T. Hryhorenko, 2021

K.M. Sukhyy, E.A. Belyanovskaya, A. Nosova, M.K. Sukhyy, Y. Huang, Yu. Kochergin, T. Hryhorenko 
halogen-containing polymers are often introduced, which are designed to increase the fire resistance of components [6].

Organotin halides (ORHs) are effective biocides, which, due to the presence of tin atoms, have antimicrobial and antifungal properties, and the presence of halogen atoms makes it possible to increase the fire resistance of paints and varnishes. Unlike metal oxides, the addition of ORH to polymeric materials does not cause secondary corrosive effects. At the same time, in seawater, ORHs are easily decomposed into products which are not dangerous for the sea fauna.

The use of ORHs for the creation of tin and halogen-containing epoxy materials is described very sparingly in the available literature. The use of ORH as reagents for the synthesis of tin-containing hardeners for epoxy resins is known [9]. The tin content in such hardeners reaches $10 \%$. However, they are not halogenated, since hydrohalic acid is released during the reaction. The use of ORH as crosslinking agents for epoxy resins requires high temperatures $\left(150-180^{\circ} \mathrm{C}\right)$ for curing, and the resulting materials are very fragile and have low strength. Moreover, the content of tin in them is only $4-7 \%$, and the halogen content is $3-5 \%$, which is insufficient to create materials with low flammability and good antifungal and antimicrobial activity. We managed to obtain compositions with a high content of tin and halogen on the basis of the products of the interaction of ORH with epoxy resins.

Currently, the properties of composites based on tin-halide resins are studied insufficiently. In this regard, the purpose of this work is to study the deformation-strength and relaxation properties of composite materials based on the product of the interaction of an epoxy resin with an organotin halide.

\section{Models and methods}

Industrial epoxy resin of the ED-16 brand with a mass fraction of epoxy groups of $17.3 \%$ and a molecular weight of 495 and the product of its interaction with organotin halide, which was dibutyltin dibromide, were selected as the objects of research. The interaction took place according to the scheme 1 , where $\mathrm{Bu}$ is referred to $\mathrm{C}_{4} \mathrm{H}_{9}$ (scheme 2). In the course of the reaction, dibutyltin dibromide was added in such an amount that free oxirane rings were retained. The result was a product with a molecular weight of 1350 and a content of epoxy groups of $10.7 \%$.

Diethylenetriaminomethylphenol was used as a hardener. Curing of the compositions was carried out according to modes I: $20^{\circ} \mathrm{C} / 240 \mathrm{~h}$ (curing without heat supply from the outside, i.e. at room temperature) and II: $20^{\circ} \mathrm{C} / 240 \mathrm{~h}+120^{\circ} \mathrm{C} / 3 \mathrm{~h}$ (curing at room temperature with subsequent heat treatment). The objects of investigation were films with a thickness of $100-150 \mu \mathrm{m}$ obtained by curing polymer compositions between two polished surfaces of metal plates coated with a thin layer of a release agent.

Determination of the glass transition temperature $T_{g}$ was carried out using a setup described elsewhere [10]. The same setup was used to study the creep process of composites at a constant mechanical stress of $10 \mathrm{MPa}$. The mechanical properties under uniaxial tension (breaking stress $\sigma_{t}$ and deformation at break $\varepsilon_{\mathrm{s}}$ ) were determined on a Polyany-type device with a rigid dynamometer and automatic recording of measured values [10]. The elastic modulus $\mathrm{E}$ was calculated from the slope of the initial portion of the $\sigma$ vs. $\varepsilon$ curve. The water absorption $\mathrm{W}$ was determined from the increment in the mass of the film samples after exposure to water for $24 \mathrm{~h}$.

The assessment of the resistance of the composite to mold was carried out in accordance with the State Standard 9.048-89 «Unified system of protection against corrosion and aging (USPACA). Technical products. Laboratory test methods for resistance to mold fungi». Method 2 was used in the tests. The essence of the method lies in the fact that the product, without cleaning from external contaminants, is contaminated with an aqueous suspension of fungal spores and kept under conditions optimal for their development for 28 days.

The oxygen index was determined according

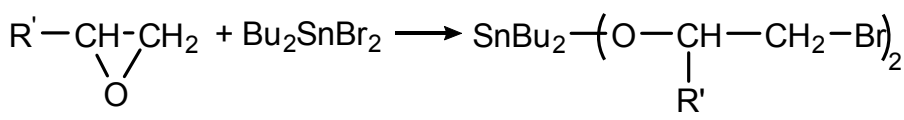

Scheme 1<smiles>[R]COc1ccc(C(C)(C)c2ccc(CC(O)COc3ccc(C(C)(C)c4ccc(OCC5CO5)cc4)cc3)cc2)cc1</smiles>

Scheme 2 
to the Standard ISO 4589-2.

The density of the nodes of the chemical network, $\mathrm{n}_{\mathrm{c}}$, was calculated by the following formula:

$$
\mathrm{n}_{\mathrm{c}}=\sigma_{0} / 3 \mathrm{RT} \varepsilon_{0}
$$

where $\sigma_{0}$ is the constant applied stress, $\mathrm{R}$ is the molar gas constant, $\varepsilon_{0}$ is the equilibrium deformation measured at temperature $\mathrm{T}=\mathrm{T}_{\mathrm{g}}+50 \mathrm{~K}$.

\section{Results and discussion}

As follows from the diagrams shown in Fig. 1, the samples based on epoxy resin containing ORH (hereinafter modified resin) are significantly inferior to those based on the original resin in terms of tensile strength, deformation at break, elastic modulus and fracture work. Apparently, this results result from the lower speed of movement of the more bulky molecules of the modified resin, as well as the presence of heavy atoms of tin and bromine in it, which, in turn, causes a decrease in molecular mobility and impedes the curing reaction when the curing agent is introduced. The result is a less dense and more defective chemical network. After heat treatment, for all samples, the values of $\sigma_{t}$ and $E$ slightly increase, while the values of the parameters $\varepsilon_{\mathrm{s}}$ and $\mathrm{A}_{\mathrm{f}}$, on the contrary, decrease, which is explained by the formation of a denser chemical network due to the additional curing of the samples when exposed to an elevated temperature.

In the resulting denser chemical network, due to the approach of molecules, the probability of the formation of a physical network by hydrogen bonds of $\mathrm{OH}$ groups and bromine atoms increases, and
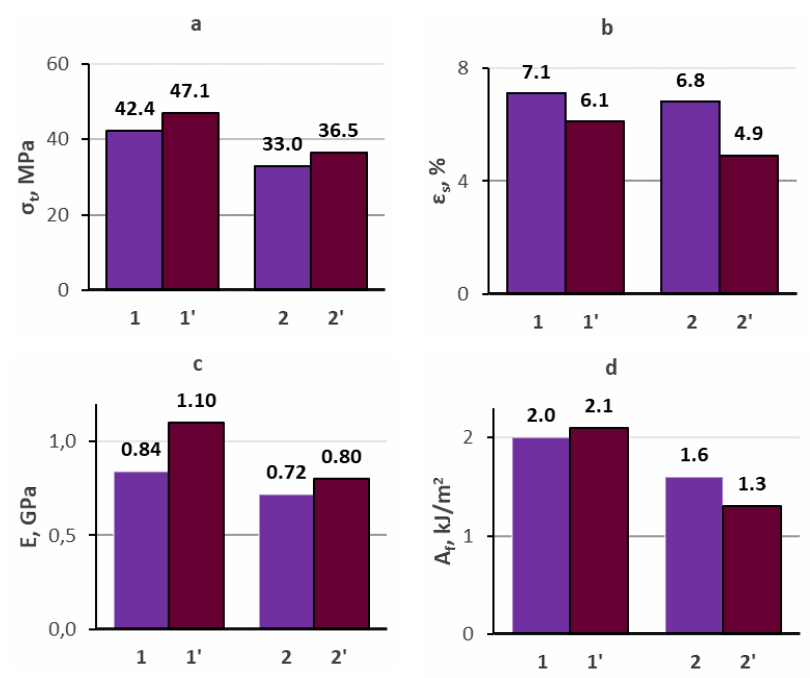

Fig. 1. Tensile strength $\sigma_{\mathrm{t}}(\mathrm{a})$, deformation at break $\varepsilon_{\mathrm{s}}(\mathrm{b})$, elastic modulus $\mathrm{E}(\mathrm{c})$, and fracture work $\mathrm{A}_{\mathrm{f}}(\mathrm{d})$ for specimens based on the original $\left(1,1^{\prime}\right)$ and modified $\left(2,2^{\prime}\right)$ resins. Specimens are cured by modes I $(1,2)$ and II $\left(1^{\prime}, 2^{\prime}\right)$ this additionally strengthens the material. As the temperature rises, the physical mesh breaks down first, and the sparser chemical mesh in modified resin composites is less resistant to mechanical stress. This is reflected in a more rapid decrease in the tensile strength (Fig. 2,a, curve 2) and a significant increase in the strain at break (Fig. 2,b, curve 2) for specimens based on the modified resin even with a slight increase in the temperature. Obviously, this behavior can be associated with an earlier devitrification of the epoxy matrix (Fig. 3,a) and the transition of the polymer to a forced elastic state.

Since tin-containing polymers are intended, first of all, to protect hydraulic structures and mechanisms operating in an aquatic environment against fouling, it was of interest to study the effect of water on their deformation and strength properties. It can be seen (Fig. 4) that the parameter $\sigma_{t}$ depends on the holding time $\left(t_{e}\right)$ of the sample in water in a complex way. At short times $\mathrm{t}_{\mathrm{e}}$ (about $24 \mathrm{~h}$ ), for a sample based on the initial resin, a decrease in $\sigma_{t}$ is observed by $10 \%$ and $33.7 \%$ for curing without heating and for a heattreated composite, respectively. For specimens based on a modified resin, the decrease in $\sigma_{t}$ for unheated and heat-treated specimens is approximately the same (29.4\% and $35.2 \%$, respectively). After reaching the minimum point, the strength increases with the appearance of a maximum at $\mathrm{t}_{\mathrm{e}}=360 \mathrm{~h}$ for specimens based on the initial resin, regardless of the curing
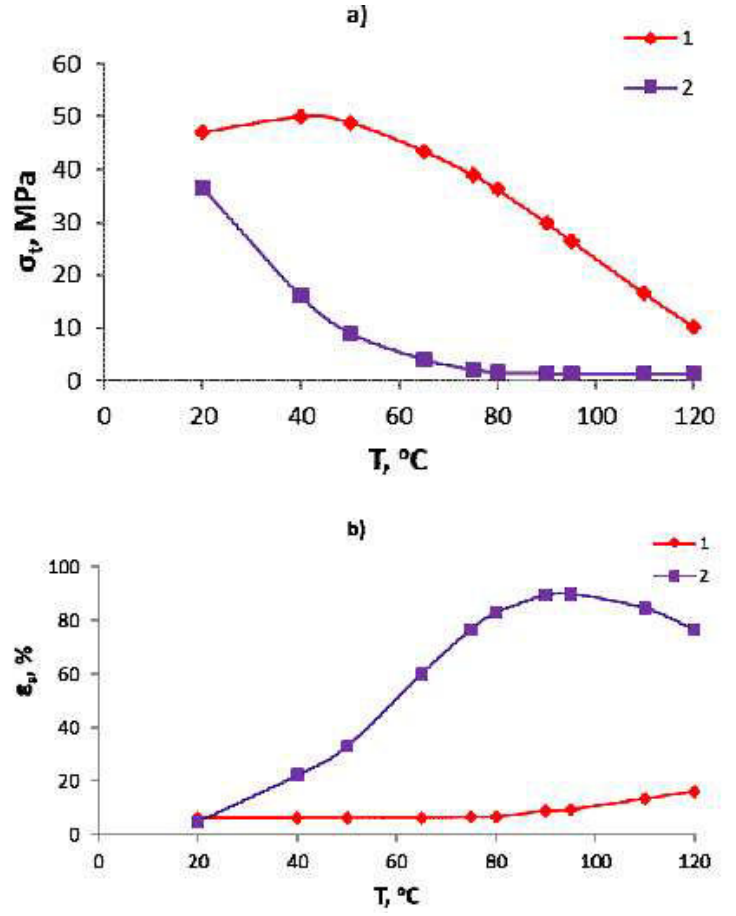

Fig. 2. Tensile strength $\sigma_{\mathrm{t}}$ (a) and deformation at rupture $\varepsilon_{\mathrm{s}}$ (b) vs. temperature for epoxide polymers based on initial (1) and modified (2) ORH resins. The specimens were cured by mode II 

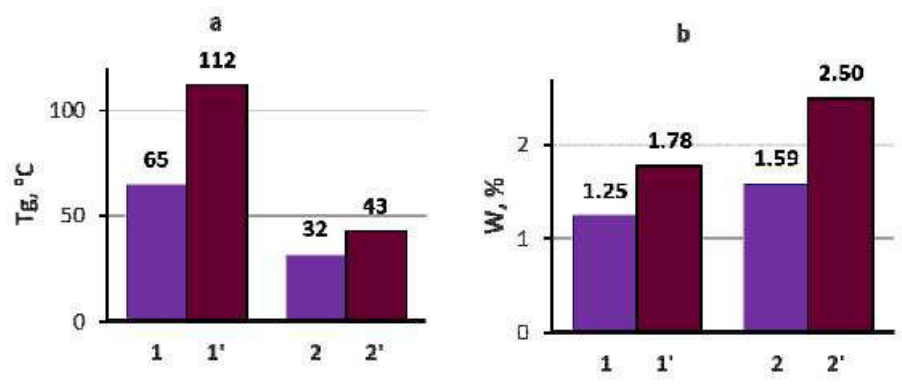

Fig. 3. Glass transition temperature Tg (a) and water absorption W (b) for samples based on the original $(1,1$ ') and modified $\left(2,2^{\prime}\right)$ resins. Specimens were cured by modes I $(1,2)$ and II $\left(1^{\prime}, 2^{\prime}\right)$

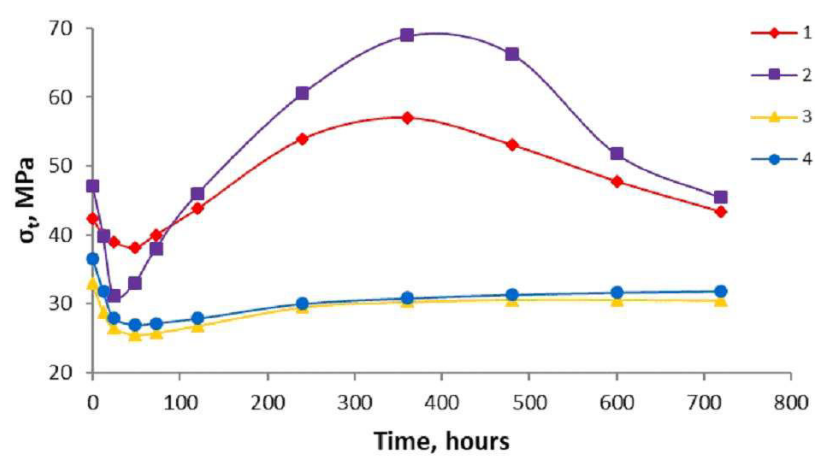

Fig. 4. Tensile strength $\sigma_{t}$ vs. exposure time $t_{e}$ in water for specimens based on initial $(1,2)$ and modified $(3,4)$ resins.

Specimens were cured by modes I $(1,3)$ and II $(2,4)$

mode. In this case, at the point of maximum, the $\sigma_{t}$ values exceed the initial values by $34.4 \%$ and $45.0 \%$ for an unheated sample and for a heat-treated sample, respectively. After the maximum, $\sigma_{\mathrm{t}}$ decreases rather quickly, reaching approximately the same values as the initial values in $720 \mathrm{~h}$ (i.e., at $\mathrm{t}_{\mathrm{e}}=0$ ).

For composites based on the modified resin, after reaching a minimum, an increase in the strength index is observed over the entire investigated range of exposure times, reaching almost a plateau at $\mathrm{t}_{\mathrm{e}}=240$ $\mathrm{h}$. In this case, the value of $\sigma_{\mathrm{t}}$ in the plateau zone is $8 \%$ lower than the initial strength value for an unheated sample and $15 \%$ lower than for the heattreated sample.

Dependences of deformation at break on exposure time in water represent (Fig. 5) extreme curves with a maximum at $\mathrm{t}_{\mathrm{e}}=24 \mathrm{~h}$ for composites cured without heating, based on both the initial and modified resin. After reaching a maximum, $\varepsilon_{\mathrm{s}}$ monotonically decreases with increasing $t_{e}$ to the values more than two times lower than for samples with $\mathrm{t}_{\mathrm{e}}=0 \mathrm{~h}$. In this case, the maximum on the $\varepsilon_{\mathrm{s}} \mathrm{vs}$. $t_{e}$ dependence for a composite based on a modified resin is more pronounced. The deformation of the sample based on the initial resin cured by mode I at the maximum point is 1.65 times greater than the initial value (at $\mathrm{t}_{\mathrm{e}}=0 \mathrm{~h}$ ). For a composite based on a

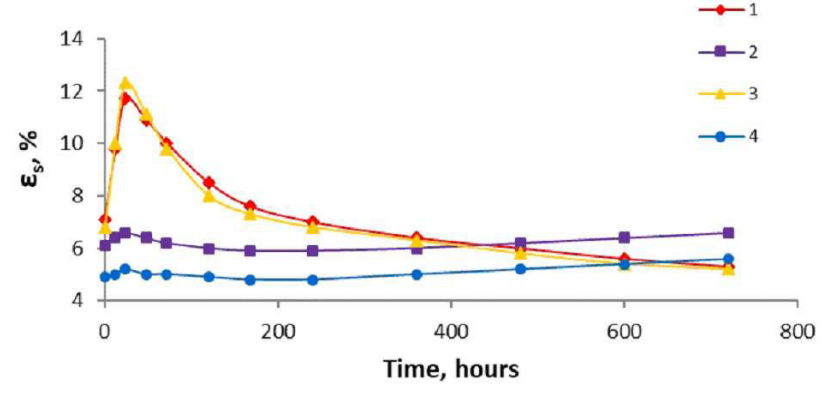

Fig. 5. Dependence of deformation at rupture $\varepsilon_{\mathrm{s}}$ vs. the exposure time $t_{e}$ in water for specimens based on the initial $(1$, $2)$ and modified $(3,4)$ resins. Specimens were cured by modes I $(1,3)$ and II $(2,4)$

modified resin, the increase in deformation is even greater and amounts to 2.03 times (Fig. 5, curve 3). For specimens post-cured at $120^{\circ} \mathrm{C}$, the $\varepsilon_{\mathrm{s}}$ maxima are less pronounced (Fig. 5, curves 2 and 4), and the deformation at rupture at $t_{\mathrm{e}}=720 \mathrm{~h}$ is higher than at $\mathrm{t}_{\mathrm{e}}=0 \mathrm{~h}$.

As follows from Fig. 6, exposure of epoxy polymers in water also leads to a change in their glass transition temperature. It can be seen that for specimens cured without heating, at short exposure times in water, the $T_{g}$ parameter decreases slightly at very short exposure times $\mathrm{t}_{\mathrm{e}}=3-5 \mathrm{~h}$ (from $65^{\circ} \mathrm{C}$ to $62^{\circ} \mathrm{C}$ ). Further, with increasing $t_{e}$, the value of $T_{g}$ begins to increase, and it is especially intense in the interval $t_{e}$ from $10 \mathrm{~h}$ to $72 \mathrm{~h}$, where the average increment of $\mathrm{T}_{\mathrm{g}}$ is about $0.25^{\circ} \mathrm{C}$ for 1 hour of water aging. In the interval $t_{e}$ from $72 \mathrm{~h}$ to $240 \mathrm{~h}$, the growth rate of $\mathrm{T}_{\mathrm{g}}$ is significantly lower $\left(0.012^{\circ} \mathrm{C} / \mathrm{h}\right)$, and at $\mathrm{t}_{\mathrm{e}}$ from $240 \mathrm{~h}$ to $720 \mathrm{~h}$ it tends to $0\left(0.0021^{\circ} \mathrm{C} / \mathrm{h}\right)$. An increase in $T_{g}$, obviously, indicates an increase in the frequency of the spatial network in the polymer. At the same time, for the heat-treated samples, $T_{g}$ decreases monotonically when exposure time both in water and in air increased (Fig. 6, curves 3 and 4).

The results of calculating the density of the chemical network $n_{c}$ confirm the assumption about 


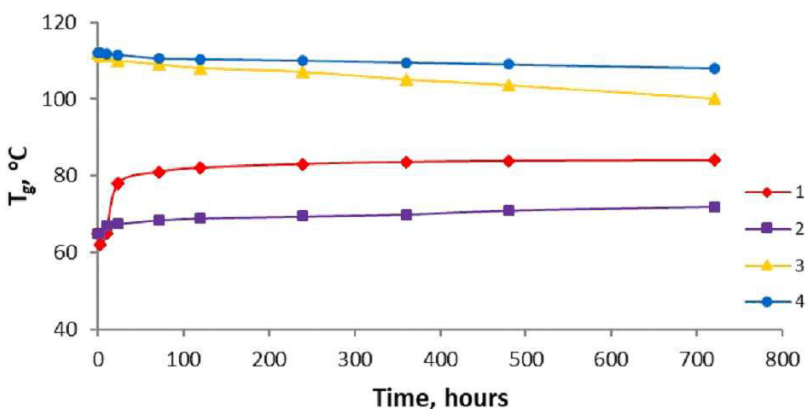

Fig. 6. Dependence of the glass transition temperature $T_{g}$ on the exposure time $t_{\mathrm{e}}$ for samples based on the original resin, cured by modes I $(1,2)$ and II $(3,4): 1$ and $3-$ exposure in water; 2 and $4-$ exposure in air

the compaction of the chemical network when the epoxy polymer is kept in water. As follows from Fig. 7, for a sample cured without heat supply from the outside, in the first hours of its exposure to water, a sharp increase in $n_{c}$ is observed, after which the rate of its increase decreases rapidly. In our opinion, ehe results obtained can be explained in the following way. Water sorbed by the polymer appears to weaken physical bonds, leading to an increase in the intensity of molecular motion. As a result, the probability of contact of unreacted reactive groups and, consequently, the formation of additional chemical crosslinks increases. In the case of aging of the samples in air, the observed changes in the parameters $\mathrm{T}_{\mathrm{g}}$ (Fig. 6, curve 2) and $\mathrm{n}_{\mathrm{c}}$ (Fig. 7, curve 2) are extremely insignificant. At the same time, they also can be largely attributed to the effect associated with the action of moisture sorbed from the air.

The observed results give grounds to speak of a significant acceleration of the process of additional curing of the epoxy polymer in water at deep stages of the conversion of reactive (epoxy and amine) groups. In this case, in a relatively short time $t_{e}=24-72 h$, the values of the parameter $n_{c}$ are achieved, which are close to those for the heat-treated sample. A slightly different picture is observed for the samples subjected to heating. Although here, too, the additional curing of the sample is observed when it is kept in water, which is reflected in a slight increase in $n_{c}$ with increasing $t_{e}$ (Fig. 7 , curve 3 ), the plasticization effect prevails, causing a monotonic decrease in $\mathrm{T}_{\mathrm{g}}$ with increasing $\mathrm{t}_{\mathrm{e}}$ (Fig. 6, curve 3). Interestingly, for a heat-treated polymer, a decrease in its heat resistance with time is observed even when it is aged in air (Fig. 6, curve 4). Apparently, this is due to the plasticizing effect of moisture sorbed from the air. The results obtained allow assuming that to ensure a higher performance of film samples based on epoxy compositions, one should strive to achieve

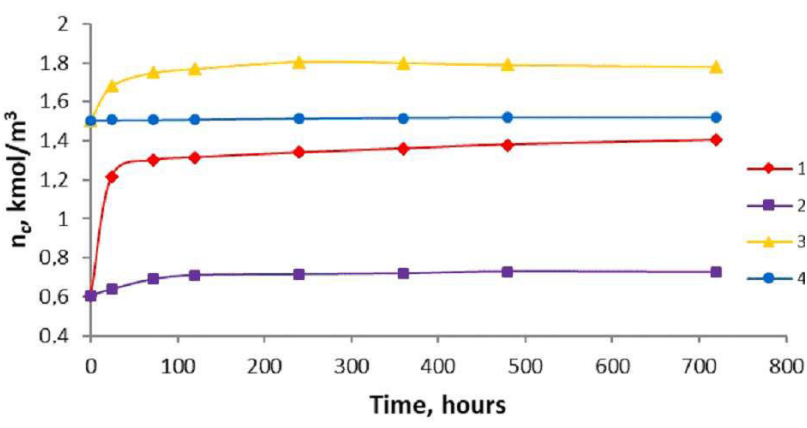

Fig. 7. Dependence of the density of the chemical network $n_{c}$ on the holding time $t_{\mathrm{e}}$ for samples based on the original resin, cured in modes I $(1,2)$ and II $(3,4): 1$ and 3 - exposure in water; 2 and $4-$ holding in air

a certain optimum, different from the limiting completeness of curing.

Assuming the superposition of the effects of plasticization and additional curing of epoxy polymers upon exposure to water, the observed change in their deformation and strength properties under the influence of a liquid medium becomes clear. At small $t_{e}$, the effect of the adsorbed moisture is mainly aimed at weakening the intermolecular interaction in the sample, as a result of which its tensile strength decreases and the deformation at break increases. At large $t_{e}$ values, when the amount of absorbed water becomes large enough and a rather intense molecular mobility develops, post-curing processes prevail, leading to an increase in the crosslinking density and, as a consequence, to a decrease in the deformation capacity and an increase in the strength index.

Based on this mechanism, it is possible to explain the nature of the change in the dependence of the elastic modulus with the course of water aging. At short times $t_{e}$, the value of $E$ decreases for all studied samples (Fig. 8), which indicates the effect of plasticization. After reaching the minimum, an increase in the modulus is observed, associated with the additional curing of the epoxy polymer, up to values approximately equal (sample based on modified resin, cured according to mode I) or even slightly higher than the initial value at $t_{e}=0 h$ (for samples based on the initial resin ED-16 regardless of cure mode and modified resin cured by mode II). At sufficiently long exposure times (over $500 \mathrm{~h}$ ) for samples based on the initial resin, the plasticization effect again prevails, as evidenced by a further decrease in the elastic modulus.

The creep curves are shown in Fig. 9. It can be seen that the samples based on the modified resin exhibit higher value and rate of creep that the samples based on the original resin. At the same time, a 


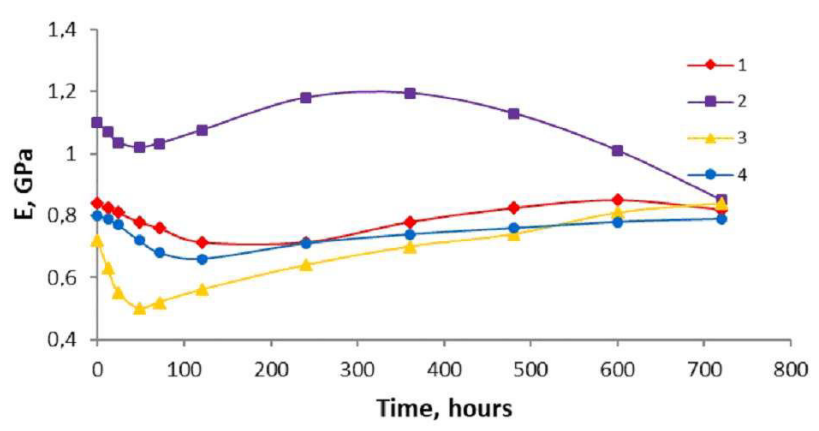

Fig. 8. Dependence of the elastic modulus E on the exposure time $t_{\mathrm{e}}$ for samples based on the original $(1,2)$ and modified $(3,4)$. Specimens were cured by modes I $(1,3)$ and II $(2,4)$

slight increase in the test temperature significantly accelerates the creep process (Fig. 9, curve 5). This circumstance must be taken into account in the case when the material is required to maintain its size and shape under the action of a load over time.

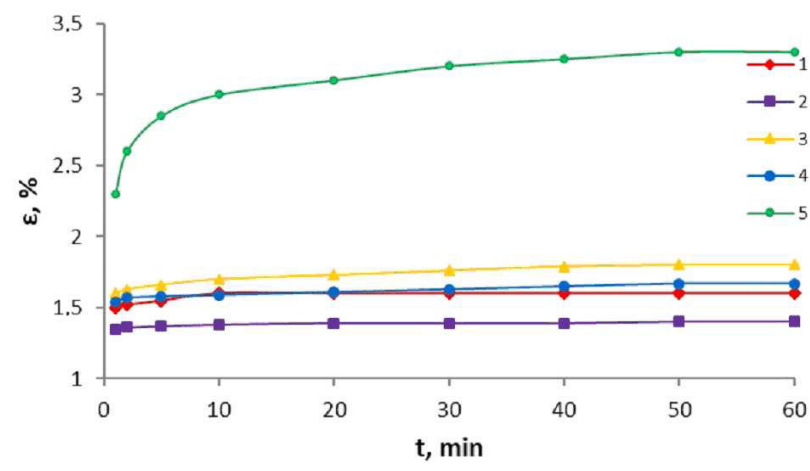

Fig. 9. Creep curves of specimens based on the initial $(1,2)$ and modified ORH $(3,4,5)$ ED-16 epoxy resin, cured by modes I $(1,3,5)$ and II $(2,4)$. Test temperature was $22^{\circ} \mathrm{C}$ $(1,2,3$, and 4$)$ and $35^{\circ} \mathrm{C}(5)$

The results of studying the creep process depending on the time of exposure of the samples to water can serve as an additional confirmation of the

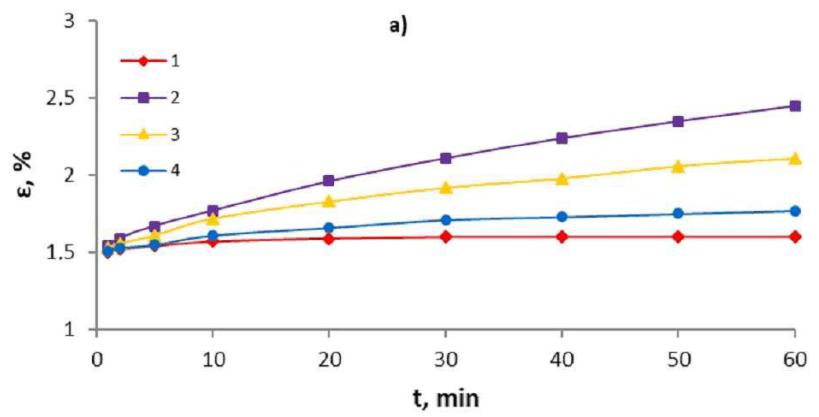

superposition of the effects of plasticization and additional curing. It can be seen (Fig. 10) that a noticeable increase in the deformability of the samples occurs only in the first $24 \mathrm{~h}$ of water aging. Further, with increasing $t_{e}$, a slowdown in the creep process is observed. As a result, a specimen held in water for $240 \mathrm{~h}$ exhibits lower deformation than a specimen for which $t_{e}$ is $24 \mathrm{~h}$. If the specimen is tested with $\mathrm{t}_{\mathrm{e}}=240 \mathrm{~h}$ in air, then its creep decreases even more and differs little from the creep of the initial sample with $t_{e}=0 h$. In this case, the sample with $t_{e}=240 h$ contains more adsorbed moisture (Fig. 3,b), which naturally plasticizes the composite. This once again emphasizes that at sufficiently long exposure times in water, the post-curing processes play a crucial role, leading to an increase in the crosslinking density of the polymer rather than the plasticization effect.

Due to the fact that the investigated polymer based on the product of interaction of epoxy resin with ORH contains $11.3 \%$ of bromine and $8.4 \%$ of tin, it has a reduced combustibility and good fungitoxicity. Its oxygen index (OI) is $27 \%$ versus $21 \%$ for polymers based on the original ED-16 resin; polymers with an OI from 20 to 27 are known [1115] to be classified as slowly combustible, while polymers with an OI $>27$ are considered to be hardly combustible and are self-extinguishing when removed from fire. Evaluation of the resistance of the composite to the effects of molds showed that it has sufficient fungitoxicity: the degree of mold growth is 0 (that is, mold growth is not observed under the microscope) versus 2 (weak mold development) for samples based on the original resin. All this expands the possible areas of application of such compositions, first of all, as antifouling and flame retardant coatings.

\section{Conclusions}

Thus, the method for the synthesis of a modified epoxy resin based on an organotin halide and an industrial epoxy resin ED-16 has been developed. Despite the fact that the epoxy composites containing a modified resin are inferior in terms of the complex

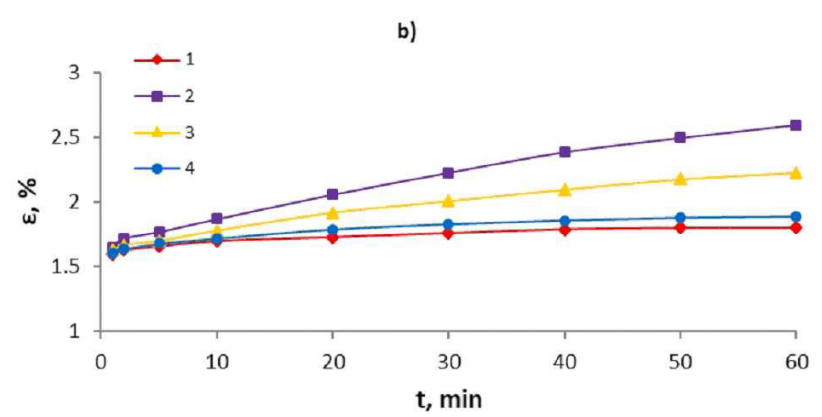

Fig. 10. Creep curves for composites based on the initial (a) and modified (b) resins cured according to mode I. The samples were soaked in water for $0(1), 24(2)$ and $240(3,4)$ hours: 1 and $4-$ air tests; 2 and 3 - in water 
of physical and mechanical properties and water resistance to materials based on the original resin, they are significantly superior to them in terms of resistance to the development of fungi and mold as well as fire resistance. The investigated polymers are promising for the production of anti-fouling coatings on their basis for hydraulic equipment operating in the presence of algae, fungi and other microorganisms in the environment.

\section{REFERENCES}

1. Звягинцев А.Ю., Полтаруха О.П., Масленников С.И. Обрастание морских систем технического водоснабжения и анализ методов защиты от обрастания в водоводах (аналитический обзор) // Вода: химия и экология. -2015 . - № 1. - C.37-60.

2. Monitoring and assessment of an industrial antifouling treatment. Seasonal effects and influence of water velocity in an open once- through seawater cooling system / Rubio D., LopezGalindo C., Casanueva J.F., Nebot E. // Appl. Therm. Eng. 2014. - Vol.67. - No. 1-2. - P.378-387.

3. Патент RU 2713354. МПК C09D163/00, C09D5/16, C08L63/00. Способ получения противообрастающей эмали // Дринберг А.С. - АО «Русские краски»; Заявл. 26.06.2019; Опубл. 04.02. 2020.

4. Патент RU 2703636 МПК C09D163/00, C09D5/16, C08L63/00. Эмаль для атмосферостойкого радиационностойкого дезактивируемого противообрастающего грибостойкого покрытия // Лысов А.А., Мещеряков Ю.Я., Карпов В.А., Ковальчук Ю.Л. - ООО «Всесоюзный научно-исследовательский институт электроизоляционных материалов», АО «Научно-исследовательский и конструкторский институт монтажной технологии- Атомстрой»; Завл. 24.12.2018; Опубл. 21.10.2019.

5. Наполнители для полимерных композиционных материалов: Справочное пособие / Под ред. П.Г. Бабаевского. - М.: Химия, 1981. -736 с.

6. Элементоорганические олигомерные модификаторы эластомерных композиций / Каблов В.Ф., Новопольцева О.М., Кейбал Н.А., Кочетков В.Г., Лапина А.Г., Крюкова Д.А. // Вестник технол. ун-та. - 2015. - Т.18. - № 14. - С.59-61.

7. Касимкина М.М., Светлов Д.А., Казначеев С.В. Исследование физико-механических свойств эпоксидных композитов с фунгицидной добавкой «Тефлекс» // Транспортное строительство. - 2009. - № 2. - С.29-30.

8. Сабадаха Е.Н., Прокопчук Н.Р., Шутова А.Л. Повышение биозащитных свойств лакокрасочного покрытия за счет биостойкости и фунгитоксичности входящих в него компонентов // Труды БГТУ. - 2017. - Сер. 2. - № 2. C.120-126.

9. Патент 3622524 США. МПК2C 08 D 30/10. Compositions of epoxy resins cured with organotin compounds /
Markowitz M., Kohn L.S. - Gentral Electric Со.; Заявл. 03.09.1968; Опубл. 23.11.1971.

10. Малкин А.Я., Аскадский А.А., Коврига В.В. Методы измерения механических свойств полимеров. - М.: Химия, 1978. $-336 \mathrm{c}$.

11. Воспламеняемость и дымообразующая способность эпоксидных композиционных материалов / Ушков В.А., Фиговский О.Л., Копытин А.В., Шувалова Е.А. // Инж. вестн. Дона. - 2017. - № 1.

12. The study of properties of composite adsorptive materials «silica gel - crystalline hydrate» for heat storage devices / Sukhyy K., Belyanovskaya E., Kovalenko V., Kotok V., Sukhyy M., Kolomiyets E., Gubynskyi M., Yeromin O., Prokopenko O. // East. Eur. J. Enterprise Technol. - 2018. - Vol.91. - No. 1. P.52-58.

13. Performance of an adsorptive heat-moisture regenerator based on silica gel-sodium sulphate / Belyanovskaya E., Rimar M., Lytovchenko R.D., Variny M., Sukhyy K.M., Yeromin O.O., Sykhyy M.P., Prokopenko E.M., Sukha I.V., Gubinskyi M.V., Kizek J. // Sustainability (Switzerland). - 2020. - Vol.12. No. 14. - Art. No. 5611.

14. Kabat O., Sytar V., Sukhyy K. Antifrictional polymer composites based on aromatic polyamide and carbon black // Chem. Chem. Technol. - 2018. - Vol.12. - No. 3. - P.326-330.

15. Role of ionene in composition of porous structure of template-synthesized silicas / Berezovska I.S., Yanishpolskii V.V., Tertykh V.A., Burmistr M.V., Sukhyy K.M. // J. Therm. Anal. Calorim. - 2006. - Vol.86. - No. 1. - P.93-96.

Received 12.03.2021

\section{ВЛАСТИВОСТІ КОМПОЗИТНИХ МАТЕРІАЛІВ НА ОСНОВІ ЕПОКСИДНОЇ СМОЛИ, МОДИФІКОВАНОЇ ДИБРОМІДОМ ДИБУТИЛОЛОВА}

\section{К.М. Сухий, О.А. Бєляновська, А.М. Носова, М.К. Сухий,} Ю. Хуанг, Ю.С. Кочергін, Т.І. Григоренко

Взаємодією промислової епоксидної смоли марки ЕД-16 з дибромідом дибутилолова отримана олово-бромовмісна смола. Здійснено порівняльне дослідження комплексу фізико-механічних і релаксаційних властивостей композитів на основі вихідної і модифікованої смол, отверджених при різних температурах. Встановлено, що композиційні матеріали на основі модифікованої смоли характеризуються меншими значеннями міцності при розтягуванні, модуля пружності, роботи руйнування і температури склування у порівнянні зі зразками на основі вихідної епоксидної смоли. Досліджено вплив води на деформаційно-міцнісні властивості композитів. Встановлено складний механізм впливу сорбованої полімером вологи на комплекс властивостей, який може бути пов'язаний з накладенням ефектів пластифікації і доотвердження епоксидної матриці. При нетривалій експозиції дія сорбованої рідини направлена головним чином на ослаблення міжмолекулярної взаємодії у зразку, внаслідок чого знижується його міцність при розтягуванні і зростає деформаційна здатність. При великих часах експозиції превалюють процеси доотвердження, що приводить до збільшення щільності поперечного зшивання i, як наслідок, 
до зниження деформаційної здатності та зростання показника міцності. Показано, що епоксидні композити, що містять смолу, модифіковану дибромідом дибутилолова, відрізняються підвищеною фунгітоксичністю і вогнестійкістю. Досліджені полімери можуть розглядатися як перспективні для одержання на їх основі протиобростаючих покриттів для гідротехнічного устаткування.

Ключові слова: епоксидний композит, дибромід дибутилолова, фізико-механічні властивості, вогнестійкість, фунгітоксичність, протиобростаючі грибостійкі покриття.

\section{PROPERTIES OF COMPOSITE MATERIALS BASED ON EPOXY RESIN MODIFIED WITH DIBUTYLTIN DIBROMIDE}

K.M. Sukhyy ${ }^{a}$, E.A. Belyanovskaya ${ }^{a}$, A. Nosova ${ }^{a,}$, M.K. Sukhyy ${ }^{a}$, Y. Huang ${ }^{b}$, Yu. Kochergin ${ }^{b}$, T. Hryhorenko ${ }^{b}$

a Ukrainian State University of Chemical Technology, Dnipro, Ukraine

b Harbin Institute of Technology, Harbin, People's Republic of China

\section{*e-mail: ikichemisty@gmail.com}

A tin-bromine-containing resin was prepared by the interaction of industrial ED-16 epoxy resin with dibutyltin dibromide. A comparative study of the physical, mechanical and relaxation properties of composites based on the original and modified resins cured at different temperatures has been carried out. It has been shown that the composite materials based on a modified resin are characterized by lower values of tensile strength, elastic modulus, fracture work and glass transition temperature as compared with the samples based on the original epoxy resin. The effect of water on the deformation and strength properties of composites was studied. A complex mechanism of the influence of moisture sorbed by the polymer on the complex of properties has been established, which may result from the imposition of the effects of plasticization and additional curing of the epoxy matrix. At short exposure times, the effect of the sorbed liquid is mainly aimed at weakening the intermolecular interaction in the sample, as a result of which its tensile strength decreases and its deformation capacity increases. At long exposure times, postcuring processes prevail, leading to an increase in the crosslinking density and, as a consequence, to a decrease in deformation capacity and an increase in the strength index. It has been shown that epoxy composites containing resin modified with dibutyltin dibromide are characterized by increased fungitoxicity and fire resistance. The studied polymers can be considered as promising for the production of antifouling coatings for hydraulic equipment on their basis

Keywords: epoxy composite; dibutyltin dibromide; physical and mechanical properties; fire resistance; fungitoxicity; antifouling fungal resistant coatings.

\section{REFERENCES}

1. Zvyagintsev AY, Poltarukha OP, Maslennikov SI. Obrastanie morskikh sistem tekhnicheskogo vodosnabzheniia i analiz metodov zashchity ot obrastaniya v vodovodakh (analiticheskii obzor) [Fouling on technical water supply marine systems and analysis of the method of protection against fouling on water conduits: a review]. Voda: Khimiya $i$ Ekologiya. 2015; (1): 37-60. (in Russian).
2. Rubio D, Lopez-Galindo C, Casanueva JF, Nebot E. Monitoring and assessment of an industrial antifouling treatment. Seasonal effects and influence of water velocity in an open oncethrough seawater cooling system. Appl Therm Eng. 2014; 67(1-2): 378-387. doi: 10.1016/j.applthermaleng.2014.03.057.

3. Drinberg AS, inventor. Stock corporation «Russkie kraski», assignee. Sposob polucheniya protivoobrastayushchei emali [Method for obtaining antifouling enamel]. Russia patent RF 2713354, 2020 Feb 04. (in Russian).

4. Lysov AA, Meshcheryakov YuYa, Karpov VA, Kovalchuk YuL, inventor. Joint-stock company «Nauchnoissledovatel'skii i konstruktorskii institut montazhnoi tekhnologii», assignee. Emal' dlya atmosferostoikogo radiatsionnostoikogo dezaktiviruemogo protivoobrastayushchego gribostoikogo pokrytiya [Enamel for weather-resistant radiation-resistant decontaminated antifouling fungus-resistant coating]. Russia patent RF 2703636 , 2019 Oct 21. (in Russian).

5. Babaevsky PG. Handbook of fillers and reinforcements for plastics. Moscow: Khimiya; 1981. 736 p. (in Russian).

6. Kablov VF, Novopoltseva OM, Keibal NA, Kochetkov VG, Lapina AG, Kryukova DA. Elementoorganicheskie oligomernye modifikatory elastomernykh kompozitsii [Hetero-organic oligomeric modifiers of elastomeric compositions]. Bulletin of the Technological University. 2015; 18(14): 59-61. (in Russian).

7. Kasimkina MM, Svetlov DA, Kaznacheev SV. Issledovanie fiziko-mekhanicheskikh svoistv epoksidnykh kompozitov s fungitsidnoi dobavkoi «Tefleks» [Investigation of physical and mechanical properties of epoxy composites with a fungicidal additive «Teflex»]. Transportnoe Stroitel'stvo. 2009; (2): 29-30. (in Russian).

8. Sabadakha EN, Prokopchuk NR, Shutova AL. Povyshenie biozashchitnykh svoistv lakokrasochnogo pokrytiya za schet biostoikosti i fungitoksichnosti vkhodiashchikh $\mathrm{v}$ nego komponentov [Increasing the bioprotective properties of the paint and varnish coating due to the biostability and fungitoxicity of its components]. Proc BSTU. 2017; 2(2): 120-126. (in Russian).

9. Markowitz M, Kohn LS, inventors. General Electric Co, assignee. Compositions of epoxy resins cured with organotin compounds. US patent 3622524, 1971 Nov 23.

10. Malkin AY, Askadsky AA, Kovriga VV. Metody izmereniya mekhanicheskikh svoystv polimerov [Methods for measuring the mechanical properties of polymers]. Moscow: Khimiya; 1978. 336 p. (in Russian).

11. Ushkov VA, Figovsky OL, Kopytin AV, Shuvalova EA. Vosplamenyaemost' i dymoobrazuyushchaya sposobnost' epoksidnykh kompozitsionnykh materialov [Flammability and smoke-forming ability of epoxy composite materials]. Eng Bull Don. 2017; (1). (in Russian).

12. Sukhyy K, Belyanovskaya E, Kovalenko V, Kotok V, Sukhyy M, Kolomiyets E, et al. The study of properties of composite adsorptive materials «silica gel - crystalline hydrate» for heat storage devices. East Eur J Enterprise Technol. 2018; 91(1): 52-58. doi: 10.15587/1729-4061.2018.123896.

13. Belyanovskaya E, Rimar M, Lytovchenko RD, Variny M, Sukhyy KM, Yeromin OO, et al. Performance of an adsorptive heat-moisture regenerator based on silica gel-sodium sulphate. Sustainability. 2020; 12(14): 5611. doi: 10.3390/su12145611.

14. Kabat O, Sytar V, Sukhyy K. Antifrictional polymer composites based on aromatic polyamide and carbon black. Chem Chem Technol. 2018; 12(3): 326-330.

doi: 10.23939/chcht12.03.326.

15. Berezovska IS, Yanishpolskii VV, Tertykh VA, Burmistr MV, Sukhyy KM. Role of ionene in composition of porous structure of template-synthesized silicas. $J$ Therm Anal Calorim. 2006; 86: 93-96. doi: 10.1007/s10973-006-7579-1. 